\title{
Short notice, big difference? The effect of temporary employment on firm competitiveness across sectors
}

\section{Romina Giuliano, Stephan Kampelmann, Benoît Mahy, and François Rycx}

This paper is one of the first to examine how the use of fixed-term employment contracts (FTCs) affects firm competitiveness (i.e. productivity, wages and profits) while controlling for key econometric issues such as time-invariant unobserved workplace characteristics, endogeneity and state dependence. We apply dynamic panel data estimation techniques to detailed Belgian linked employer-employee data covering all years from 1999 to 2010. Results show that the effects of FTCs on firm competitiveness vary across sectors: while temporary employment is found to enhance productivity and profits in (labourintensive) services, this is not the case in manufacturing and construction.

Keywords: Fixed-term contracts; productivity; wages; profits, linked panel data, sectors.

JEL codes: D24, J24, J31, M12.

CEB Working Paper No 17/008

February 2017

Université Libre de Bruxelles - Solvay Brussels School of Economics and Management Centre Emile Bernheim 


\title{
Short notice, big difference? The effect of temporary employment on firm competitiveness across sectors
}

\author{
Romina Giuliano \\ Université de Mons (UMons), HumanOrg \\ Stephan Kampelmann \\ Université libre de Bruxelles (ULB), CEB and DULBEA \\ Benoît Mahy \\ Université de Mons (UMons), HumanOrg \\ François Rycx \\ Université libre de Bruxelles (ULB), CEB and DULBEA; \\ Université catholique de Louvain (UCL), IRES; \\ Université de Mons (UMons), HumanOrg; and IZA
}

\begin{abstract}
This paper is one of the first to examine how the use of fixed-term employment contracts (FTCs) affects firm competitiveness (i.e. productivity, wages and profits) while controlling for key econometric issues such as time-invariant unobserved workplace characteristics, endogeneity and state dependence. We apply dynamic panel data estimation techniques to detailed Belgian linked employer-employee data covering all years from 1999 to 2010. Results show that the effects of FTCs on firm competitiveness vary across sectors: while temporary employment is found to enhance productivity and profits in (labour-intensive) services, this is not the case in manufacturing and construction.
\end{abstract}

Keywords: Fixed-term contracts; productivity; wages; profits, linked panel data, sectors.

JEL codes: D24, J24, J31, M12

Acknowledgements: We are most grateful to Statistics Belgium for giving access to the data. Funding for this research (EDIPO project) was provided by the Belgian Science Policy Office (BELSPO). 


\section{Introduction}

A nuanced understanding of the different repercussions of fixed-term employment contracts (FTCs) has emerged as an increasingly salient problem in labour economics and the study of employment relations. In the 1980s and 1990s, FTCs were widely regarded as an effective tool for injecting more flexibility into 'ossified' labour markets. They also seemed to fit better to the Japanese 'lean production' model that replaced traditional inventory-heavy models in many advanced economies in the 1990s (Dhyne and Mahy, 2012). Eager to adapt labour markets to an apparent demand for more flexibility, legislators in most industrialised economies relaxed laws regarding temporary employment (Bentolila and Bertola 1990; Mahy 2005) and the average share of FTCs in OECD countries increased from $9.2 \%$ in 1980 to $10 \%$ in 1990; by 2000 the share reached $11.3 \%$. Since the late 1990s, the OECD average of FCTs ceased to grow and oscillated between 11 and 12\%; compared to 2003, the proportion of FCTs in 2013 slightly declined in some countries (OECD LFS Database 2015). Considering that in most countries roughly one out of ten employees works on a contract with a fixed term, this work arrangement remains one of the most widespread forms of nonstandard or atypical employment. We propose to study the repercussions of FTCs with data from Belgium; the latter provides for a good case study as fixed-term employment in this country has been very stable around 8.5\% over the last 15 years and legislation and labour policies regarding FTCs have also been more consistent and stable compared to other countries. While there is an extensive literature on the many issues related to the flexibilisation of employment relations - with a central strand going back to theories of labour market dualization developed in the 1970s (Boeri 2011; Piore 1978) - this paper sets out to address four key questions related to FTCs that only few contributions in the literature have so far treated frontally.

\section{What is the relationship between FTCs and productivity?}

There is no shortage of theoretical speculations regarding the impact of FTCs on productivity. Low separation costs can lead to the hold-up problem described by Teulings and Hartog (1998), in which workers bear the cost of firm-specific human capital investments but reap only a share of the benefits from higher productivity. FTCs make separation easier and therefore discourage workers from investing in match-specific human capital, thus leading to sub-optimal investments in training and skills (Belot et al., 2007). Conversely, temporary contracts have been interpreted as a buffer for product demand fluctuations and therefore as vectors of higher labour productivity over the entire business cycle (Jahn et al., 2012). Unfortunately, only few studies have actually been able to measure accurately productivity differences between temporary and permanent workers. As a consequence, the relationship between FTCs and productivity has not been clearly established and the few existing empirical studies 
do not reach the same conclusions (Damiani and Pompei 2010; Leclair and Roux 2007; Nielen and Schiersch 2012). And while some papers address the potential endogeneity of FTCs or the state dependency of productivity, a serious deficiency of some of these studies is that they fail to control for these estimation biases. By contrast, our paper is one of the first to measure how FTCs affect firm-level productivity by using a generalized method of moments (GMM) estimator that allows us to account for firm-level invariant heterogeneity, endogeneity and state dependence. Our estimates are based on detailed linked employer-employee panel data from Belgium for the years 1999-2010 that covers most of the private sector; provides accurate information on average productivity (i.e. the average value added per hour worked); and includes a wide range of worker and firm characteristics.

\section{How do FTCs affect wages?}

A growing literature examines the impact of employment contracts on wages. Empirical results typically document a significant wage gap between employees with FTCs and permanent contracts (PCs). This gap has been attributed to substantial heterogeneity across jobs and/or individuals (Bosio 2014; Brown and Sessions 2003; Comi and Grasseni 2012; De la Rica 2004). Yet a significant fraction remains unexplained after controlling for observable heterogeneity. This may suggest wage discrimination against workers with FTCs, but could also be linked to productivity differences between FTCs and PCs that are not captured by the observable characteristics of the individual and her job. Traditional approaches to measure wage discrimination between FTC and PC have relied on OaxacaBlinder decomposition methods, but have been severely criticised for not being able to account accurately for potential productivity differences (Bartolucci, 2014). In this paper we overcome this issue by simultaneously estimating both productivity and wage equations with matched employeremployee panel data. Following Bartolucci (2014), a difference between the wage and productivity coefficients of the two equations can be interpreted as evidence for wage discrimination.

\section{How do FTC affect profits and firm competitivess?}

From the employers' perspective, neither productivity nor wage gaps between FTCs and PCs are in themselves important: what matters for them are profits, i.e. the difference between the impact of each group on added value and wage costs. If FTCs push wages downward while being associated with a positive or only slightly negative effect on productivity, then this gives rise to a rent captured by the employer. Conversely, if FTCs lower productivity without leading to an equivalent wage penalty for FTC workers, then this will hurt the firm's competitivess and lower its profits. In light of the theoretical literature we review below, both scenarios are plausible. Given the many different factors at play, we put forward the hypothesis that FTCs could exercise a different effect on wages and productivity and 
therefore lead to either rents (and higher firm competitiveness) or a reduction in profits (and lower firm competitiveness). We are able to test this hypothesis by estimating firm-level equations with profit per hour as dependent variable.

\section{Why do we observe differences across sectors?}

Finally, a stylised fact that has so far not received much attention refers to sectoral differences in the incidence of FTCs. Indeed, the average share of temporary employment in OECD countries is higher in services than in manufacturing; in countries like the US, the UK, Germany and Belgium the share is between 1 and 3 percentage points higher in services (OECD 2002, 2015). This raises the question why employers in certain sectors make more use of temporary work than in others. If employers maximise profits, the optimal use of FTCs depends of course on the nature of the production unit; but notwithstanding a few exceptions (notably Damiani and Pompei 2010; Leclair and Roux 2007), so far little is known on how the relationship between temporary contracts and firm competitiveness varies across sectors. These variations, however, are likely to be significant given that sectors differ with respect to the importance of firm-specific skills, product demand fluctuations and unionization (Blerot et al. 2007; Damiani and Pompei 2010). We fill this gap in the literature by measuring empirically whether the impact of temporary jobs on the productivity-wage nexus varies across manufacturing and services (as well across more detailed sectors).

The remainder of the paper is organized as follows. A review of the literature regarding the relationship between employment contracts, wages and productivity is presented in the next section. The following two sections describe respectively our methodology and data set. We then measure the impact of FTCs on productivity, wages and productivity-wage gaps across industries and discuss our results. The final section concludes.

\section{Theoretical and empirical background}

Most theories predicting productivity-wage gaps are formulated without specific reference to employment contracts. In this section, we show how the most prominent of these theories can be adapted to account for differences between FTCs and PCs. 


\section{Human capital}

A first set of explanations that can be applied to the relationship between FTCs, wages and productivity are theories of compensating wage differentials, such as human capital theory and hedonic wage theory. Human capital theory posits that employers might be more reluctant to invest in training for FTC workers if the shorter employment period of the latter means that they benefit less from on-the-job training (Bassanini et al. 2007). Due to the hold-up problem mentioned above, the investments of employees in firm-specific skills might also be sub-optimal as FTCs lower separation costs and therefore deteriorate the bargaining position of employees concerning the distribution of the benefits of firm-specific human capital (Belot et al., 2007). It should, however, be noted that human capital differences between FTC and PC workers does not necessarily affect the profitability of firms if workers are paid according to their marginal product.

As for empirical evidence on the human capital of FTC workers, various studies suggest lower investments in human capital for FTC employment (Arulampalam and Booth 1998; Booth et al. 2002; Fouarge et al. 2012). Other authors show that FTC workers are generally less qualified and overrepresented among young people, which is in line with their lower labour market experience and tenure (see Eurostat 2012). Moreover, empirical results for Spain showing that diversity in observed skills explains more than 50\% of wage differentials between FTC and PC workers (De la Rica 2004). Using a panel of Italian private sector firms, Cappellari et al. (2012) find that the deregulation of FTCs in the early 2000s led to (small and weakly significant) productivity losses. By contrast, Nielen and Schiersch (2012) show, on the basis of a large dataset of German manufacturing firms, that FTCs have no significant effect on labour productivity.

Belgium is an interesting case as the labour legislation in this country has tried to limit the use of FTCs as a means to decrease the bargaining power of employees. According to a Directive from 1999 ${ }^{\mathrm{i}}$, employers are not allowed to offer several successive FTCs for a period that exceeds two years. In this case the use of a FTC is not warranted as it arguably reflects only the interests of the employer side to lower separation costs while still employing the worker for a long period of time. The legally binding maximum duration of two years of temporary employments with the same employer could, however, exacerbate the suboptimally low investments in firm-specific human capital in Belgium and we therefore expect this effect to be salient in this country. 


\section{Asymmetric information and screening}

Information asymmetry regarding the quality of labour could also be relevant for explaining potential productivity-wage gaps associated to FTCs. For instance, workers hired on FTCs could be more productive than their colleagues with PCs if the former wish to send a positive signal to their employer so as to increase the likelihood of obtaining a PC (Dhyne and Mahy 2012): in this case the FTC workers are relatively more productive without immediately enjoying higher wages, thereby leading to positive employer rents. A complementary 'screening' argument is that firms offering PCs only to the most productive FTCs will increase their productivity (Nielen and Schiersch, 2012). Tournament theory has formalised this relationship and argues that firms deal with asymmetric information through performance-related tournaments in which a prize is attributed to the most productive worker (Lazear and Rosen, 1981). This system aims to trigger competition and to encourage workers to provide sustained effort in order to obtain the prize. It is fully conceivable that employers use PCs as a prize in tournaments among workers on FTCs.

Engellandt and Riphahn (2005) corroborate the implication of higher effort of FTC workers with Swiss data and find that being on a FTC increases the probability of doing unpaid overtime by about $60 \%$. Moreover, Dolado and Stucchi (2008) show that temporary workers in Spain provide more effort in firms in which the transition rate from a temporary to a permanent contract is higher.

\section{Demand fluctuations and adjustment costs}

A prominent interpretation of the use of FTCs is that they allow firms to adjust their workforce to business-cycle fluctuations at relatively low termination costs (Nielen and Schiersch 2012). This has repercussions on the relative productivity of FTCs and PCs. If firms succesfully use the former to dipose of sufficient labour when demand is high, this will positively affect the relative productivity of FTC workers: contrary to their colleagues with PCs, they only appear on the payroll in busy periods with hikes in per hour production, whereas PC workers are also in the firm when business is slow and per hour output is sluggish. Nunziata and Staffolani (2007) developed a model in which the probability of using FTCs depends on the volatility in product demand. In general, labour adjustment costs (i.e. hiring and separation costs) play a potential role for the productvity and wages of FTCs. In dynamic labour demand models, adjustment costs are considered as 'quasi-fixed' and amortized over a worker's average length of service within a firm so that workers are no longer paid according to their marginal productivity (Oi 1962). Given that adjustment costs (notably firing costs) are generally lower for FTC workers (Dhyne and Mahy 2012), this model predicts that the gap between productivity and wages is larger for PC workers. This being said, Nielen and Schiersch (2012) note that the flexibility of FTC 
employment is imperfect because dismissing FTC workers without lay-off costs is only possible at the end of employment contracts.

There is some empirical evidence that FTCs allow firms to boost productvity by adjusting to fluctuations in product demand, for instance in form of the studies by Houseman (2001) and Vidal and Tigges (2009).

\section{Collective bargaining}

In most advanced economies, temporary workers are less likely to be affiliated with a trade union than workers on permanent contracts (Riley 1997; Salvatori 2009). Trade unions may thus be more willing to defend the interests of the latter, notably with respect to wages, although they may also protect fragile workers - including those with temporary contracts - against monoposnistic power of certain employers (Manning 2003). Moreover, temporary workers may suffer from a wage penalty if firms compensate wage increases for permanent workers by imposing wage restraints for temporary employees (Heery 2004). In line with dual and insider-outsider labour market theories (Lindbeck and Snower 1986; Piore 1978), PC workers’ employment protection and bargaining power could increase with the share of FTCs as the latter effectively function as a buffer during economic downturns.

Brown and Sessions (2003) find empirical evidence for wage discrimination against FTC workers in the UK, highlighting that union coverage only improves wages of permanent workers. Jimeno and Toharia (1993) find that FTC employees in Spain perceive lower wages than their permanent counterparts after controlling for observable individual and job characteristics.

The legislation in Belgium has tried to curb unjustified wage penalties against FTC workers through anti-discrimination legislation that has been agreed upon by the social partners in 2002. ${ }^{\text {ii }}$ This legislation stipulates the principle that workers cannot be treated differently in terms of their remuneration or working conditions on the grounds of their temporary employment with the firm. This principle has been backed by all major trade unions in this country and is likely to have limited the extent of wage penalties against FTC workers in Belgium compared to other countries with less stringent anti-discrimination legislation that specifically protects workers with temporary contracts.

\section{Sectors}

Sectors are often considered to differ with respect to the two previous dimensions, i.e. the extent of product demand fluctuation and collective bargaining. This suggests that the incidence of FTCs and 
their productivity are relatively higher in sectors with stronger product demand fluctuations - especially in activities that do not allow for the creation of stocks such as in restaurants or hotels. Moreover, as argued above, the differences between FTCs and PCs in terms of productivity and wages could be sensitive to the bargaining power of unions which typically differs across sectors.

Empirical results by Leclair and Roux (2007) based on French firm-level panel data indeed suggest that the impact of temporary employment on firm competitiveness varies across industries: while temporary employment is found to enhance productivity and profits in services, the effects turn out to be insignificant in the manufacturing industry. However, using sector-level data covering 16 European countries, Damiani and Pompei (2010) show that FTCs in labour-intensive sectors, such as services, discourage human capital investments and deteriorate multifactor productivity.

\section{Measurement methods}

The test developed in this article is based on the estimation of a value added function and a wage cost equation at the firm level. The value added function yields parameter estimates for the average marginal products of workers with permanent and fixed-term contracts respectively, while the wage equation estimates the respective impact of each type of employment contract on the average wage bill paid by the firm. Given that both equations are estimated on the same samples with identical control variables, the parameters for marginal products and wages can be compared and conclusions can be drawn on how the use of FTCs affects firm competitiveness (i.e. productivity-wage gaps). More specifically, if for a certain type of labour the productivity coefficient is higher (lower) compared to the labour cost coefficient, then this is interpreted as these workers being paid below (above) their marginal products.

This technique was pioneered by Hellerstein and Neumark (1995) and refined by Hellerstein et al. (1999), Hellerstein and Neumark (2004) and van Ours and Stoeldraijer (2011) among others. It is now standard in the literature on the productivity and wage effects of labour heterogeneity (see e.g. Cardoso et al., 2011; Garnero et al. 2014a; Göbel and Zwick 2012; Mahlmberg et al., 2013).

The estimated firm-level productivity and wage cost equations are the following:

$$
\ln (\text { Value Added } / \text { Hours })_{i, t}=\alpha+\beta_{1} F_{T C}+\beta_{2} \text { OTC }_{i, t}+\lambda X_{i, t}+\varepsilon_{i, t}
$$


$\ln (\text { Wage Cost } / \text { Hours })_{i, t}=\alpha^{*}+\beta_{1}^{*} F_{T C}+\beta_{2}^{*} O T C_{i, t}+\lambda^{*} X_{i, t}+\varepsilon_{i, t}^{*}$

The dependent variable in equation (1) is firm i's hourly value added, obtained by dividing the total value added (at factor costs) of firm $i$ in period $t$ by the total number of hours worked (taking into account paid overtime hours) that have been declared for the same period. The dependent variable in equation (2) is firm i's average wage bill (including payroll taxes and variable pay components, such as wage premia for overtime, weekend or night work, performance bonuses and other premia). It is obtained by dividing the firm's total wage cost by the total number of hours worked. Hence, the dependent variables in the estimated equations are firm averages of value added and wage costs (net of social security payroll tax cuts) on an hourly basis.

The main variable of interest, $F T C_{i, t}$, is the proportion of hours paid to workers on a FTC over the total amount of hours paid within the firm. OTC $C_{i, t}$ corresponds to the share of employees with other types of contracts (in our database notably apprentices). Note that our focus will be on FTCs and not on apprentices as the effects of the latter on firm competitiveness are considered in a specific literature. In addition, equation (1) includes the vector $X_{i, t}$. It contains a set of variables controlling for observable worker, job and firm characteristics. More precisely, it includes the share of the workforce within a firm that: (i) has at most lower secondary education and a degree from tertiary education, respectively, (ii) has at least 10 years of tenure, (iii) is younger than 30 and older than 49 years, respectively, (iv) is female, (v) works part-time, and (vi) occupies blue-collar jobs. $X_{i, t}$ also comprises the natural logarithm of firm size (i.e. the number of full-time equivalent workers), the natural logarithm of the capital stock per worker ${ }^{\mathrm{iii}}$, the level of collective wage bargaining (1 dummy), sectoral affiliation (8 dummies), the region where the firm is located (2 dummies), and 11 year dummies. ${ }^{\text {iv }}$

Estimating equations (1) and (2) allows gauging the effect of FTCs on firm productivity and wage costs, but it does not allow testing directly whether the difference between the value added and the wage cost coefficients associated to our main variable of interest is statistically significant. A simple method to obtain a test for the significance of productivity-wage gaps has been proposed by van Ours and Stoeldraijer (2011). We apply a similar approach and estimate a model in which the profit, the gap between firm i's hourly value added and hourly wage (i.e. the hourly gross operating surplus) is regressed on the same set of explanatory variables as in equations (1) and (2). This produces a coefficient for the share of FTCs and directly measures the size and significance of the productivitywage gap. We estimate thus equation (3): 
$\ln (\text { Gross profit/Hours })_{i, t}=\alpha^{* *}+\beta_{1}^{* *}$ FTC $_{i, t}+\beta_{2}^{* *}$ OTC $C_{i, t}+\lambda^{* *} X_{i, t}+\varepsilon_{i, t}^{* *}$

Equations (1) to (3), have been estimated with three different methods: pooled ordinary least squares (OLS), a fixed-effects (FE) model and the generalized method of moments (GMM) estimator developed by Arellano and Bover (1995) and Blundell and Bond (1998). The OLS estimator is based on the cross-section variability between firms and the longitudinal variability within firms over time. However, this OLS estimator suffers from a potential heterogeneity bias because firm productivity can be related to firm-specific, time-invariant characteristics that are not measured in micro-level surveys (e.g. an advantageous location, firm-specific assets such as patent ownership, or other firm idiosyncrasies).

While estimating a FE model enables to control for time-invariant unobserved firm characteristics, it does not address the potential endogeneity of the explanatory variables. The composition of the firm's workforce is likely to be endogenous for several reasons. First, workers might choose or accept working with permanent or fixed-term contracts according to their degree of job commitment. Second, in periods of cyclical downturn firms might be more likely to reduce personnel among workers with a FTC as adjustment costs are typically lower for the latter. In order to tackle this endogeneity issue, in addition to temporal persistence in the dependent variable (firm productivity, wage costs or profits) $^{\mathrm{v}}$ and firm fixed unobserved heterogeneity, we estimate equations (1) to (3) with the dynamic system GMM (GMM-SYS). ${ }^{\text {vi }}$

The GMM-SYS approach boils down to simultaneously estimating a system of two equations (one in level and one in first differences) and to relying on 'internal instruments' to control for endogeneity. The inclusion of a differenced equation in the GMM-SYS ensures that firm fixed effects are taken into account. More precisely, the FTC variable ${ }^{\text {vii }}$ in the differenced equation is instrumented by its lagged levels and the FTC variable in the level equation is instrumented by its lagged differences. ${ }^{\text {viii }}$ The implicit assumption is that changes (the level) in (of) the dependent variable - productivity or wages in one period, although possibly correlated with contemporaneous variations (levels) in (of) the FTC variable, are uncorrelated with lagged levels (differences) of the latter. Moreover, changes (levels) in (of) the FTC variable are assumed to be reasonably correlated to their past levels (changes). The theoretical rationale for our IV strategy is that the level/changes in productivity, labour costs and profits (our dependent variables) are directly related to the level/changes in FTC shares for the same time period (our independent variables) and not past values of FTC shares (our instruments). ${ }^{\text {ix }}$ For instance, 
the labour costs of a firm are arguably related to the current incidence of FTCs in its workforce but not directly to the share of FTCs it has employed in the past. The rationale for including the latter as instruments is the relationship between the past and present structures of the workforce: a high level of FTCs in the past has repercussions on how the share will change over time. If, for example, a firm has employed almost only FTC workers in $t-1$, its ability to increase the proportion of FTCs in $t$ are limited, even in the event of a positive demand shock in year $t$.One advantage of the system GMM is that timeinvariant explanatory variables can be included among the regressors, while they typically disappear in difference GMM. Asymptotically, the inclusion of these variables does not affect the estimates of the other regressors because instruments in the level equation (i.e. lagged differences of educational variables) are expected to be orthogonal to all time-invariant variables (Roodman, 2009). To examine the validity of our estimates, we apply Hansen's (1982) and Arellano-Bond's (1991) tests. The first is a test for overidentification which allows to test the validity of the instruments. The second is a test for autocorrelation, where the null hypothesis assumes no second order autocorrelation in the first differenced errors. The non-rejection of the two tests is required in order to assume that our estimates are reliable. In order to be as parsimonious as possible, we choose the model with the minimum number of lags that passes both tests. ${ }^{\mathrm{x}}$

The adoption of a dynamic GMM specification aims to account for the persistence in firm-level profits, wage costs and productivity. It is also likely to improve the identification of the parameters of interest (even though the coefficient on the lagged dependent variable is not a central issue in the analysis). Indeed, as illustrated by Bond (2002), the use of a dynamic model is necessary to obtain consistent results when estimating a production function with serially correlated productivity shocks and explanatory variables that are correlated to these shocks. While serial correlation of productivity shocks may arise if for instance the effects of demand shocks are only partially captured by the industryspecific control variables (Hempell, 2005), the responsiveness of input factors to productivity shocks may be explained by the above-mentioned endogeneity issue. Interestingly, the inclusion of the lagged dependent variable in the OLS, fixed-effects and system GMM specifications also provides an ad hoc test for the appropriateness of the latter. As outlined by Roodman (2009), this test consists in checking whether or not the regression coefficient on the lagged dependent variable obtained with system GMM falls between the OLS and fixed effects estimates. 


\section{Data and descriptive statistics}

We use a combination of two large datasets covering the years 1999-2010. The first is the 'Structure of Earnings Survey' (SES), carried out by Statistics Belgium. It covers all firms that are operating in Belgium, employ more than 10 workers and have economic activities within sections $\mathrm{C}$ to $\mathrm{K}$ of the NACE Rev. 1 nomenclature. ${ }^{x i}$ This survey gathers information on firms' characteristics (e.g. sector, region where the firm is located, number of workers, level of collective wage bargaining) as well as information on workers' characteristics (e.g. age, education, tenure, paid hours, sex, occupation, employment contract). Our data also include information on the characteristics of temporary agency workers. This information is provided by the human resource department of the client firm that employs these workers. However, the SES does not provide any financial information. It has thus been merged with a firm-level survey, namely the 'Structure of Business Survey' (SBS), also carried out by Statistics Belgium. This survey provides financial information (e.g. firm-level wage cost, investments, intermediate inputs, value added and gross operating surplus per hour worked). The wage costs we use in the regression analysis are gross wages and contain social security contributions and personal income taxes.

The coverage of the SBS differs from that of the SES in that it does not cover the whole financial sector (NACE J) but only Other Financial Intermediation (NACE 652) and Activities Auxiliary to Financial Intermediation (NACE 67). The merger of the SES and SBS datasets has been carried out by Statistics Belgium using firms’ social security numbers.

Information in the SES refers to the month of October of each year, while data in the SBS are measured over entire calendar years, i.e. from January to December. To avoid running a regression where information on the dependent variable (collected for the entire year) precedes the recording of the explanatory variables (collected in October), all explanatory variables in equation (1) have been lagged by one year. This way, information on FTCs is recorded in October in year $t$ and used to explain firmlevel productivity, wage costs and profits during the calendar year $t+1$. The imperfect synchronization of the SBS and SES data might introduce some fuzziness into our estimates since we cannot exclude the occurrence of external events influencing firm performance in the intermediate period. This concern could only be completely eliminated if we had firm-level information on FTCs for the entire calendar year. This being said, even if this information were available, there are also arguments for using asynchronised information on FTCs: it is difficult to conceive how changes in shares of workers with a FTC could generate immediate effects notably on firm productivity and profits. For instance, the 
potential productivity and profit effects from hiring additional workers on FTCs are likely to materialize only after the new staff has been properly trained and effectively integrated into the production process of the organisation. A second concern is that the information on workers collected in October reflect the seasonal specificity of autumn months, whereas the financial variables on firms are averages of all seasons. Compared to summer and winter months, however, the seasonal specificities of October are arguably less problematic. Thirdly, if product demand fluctuations moderate the effects of FTCs on productivity, labour costs and profits, then the data frequency should match the frequency of demand fluctuations. In the case of our data it is possible that some product demand fluctuations occur within the same year, so that the FTC shares recorded in October of the previous year could reflect a different business reality. In other words, our data will miss potential variations in FTC shares that occur through the year and that could be a response to seasonal and/or cyclical fluctuations with frequencies that are shorter than a calendar year. This important caveat is less problematic if product demand fluctuations occur over time horizons of more than a year. On any account the slightly asynchronised use of SBS and SES is the best option in light of data availability.

As a consequence, our sample contains firms that are observed in at least two consecutive years and thus over-represents medium-sized and large firms since the sampling percentages for each firm in our dataset increase with the size of the latter. ${ }^{\text {xii }}$ Next, we exclude workers and firms for which data are missing or inaccurate. ${ }^{\text {xiii }}$ Finally, we drop firms with fewer than 10 observations, because the use of average values at the firm level requires a suitable number of observations. ${ }^{\text {xiv }}$ Our final sample covering the period 1999-2010 consists of an unbalanced panel of 6,713 firm-year-observations from 1,844 firms. It is representative of all medium-sized and large firms in the Belgian private sector, with the exception of large parts of the financial sector (NACE J) and the electricity, gas and water supply industry (NACE E).

[Insert Table 1 about here]

Descriptive statistics of selected variables are presented in Table 1. We observe that firms have a mean value added per hour worked of 66.19 EUR and that workers' mean hourly wage cost stands at 33.34 EUR. Average hourly profits (i.e. gross operating surplus) are equal to 32.85 EUR. The average share of workers with a FTC stands at 3\% within firms. ${ }^{\mathrm{xv}}$ We also observe that around $27 \%$ of workers have a degree from tertiary education, 61\% are prime-age workers (i.e. aged between 30 and 49 years) 27\% are women, 55\% are blue-collar, $40 \%$ have at least ten year of tenure, and $16 \%$ occupy part-time jobs. Employees in our sample are essentially concentrated in the following sectors: manufacturing (58\%), 
wholesale and retail trade, including repair of motor vehicles, motorcycles and personal and household goods (12\%), real estate, renting and business activities (10\%), construction (10\%), and transport, storage and communication (6\%).

At the individual level, we observe that permanent workers are employed in firms in which hourly productivity and profits are both significantly higher. In contrast, hourly wage costs are found to be lower for workers with a FTC (i.e. 26.90 vs 31.15 EUR for permanent workers). Workers with a FTC are also found to be younger, less educated and more likely to be female and employed on part-time basis than their permanent counterparts. As regards sectoral affiliation, fixed-term jobs tend to be overrepresented in the wholesale and retail trade sector (including repair of motor vehicles, motorcycles and personal and household goods) and in real estate, renting and business activities. In contrast, they are under-represented in the manufacturing and construction industries. Finally, we observe that fixed-term workers are somewhat less likely to be covered by a firm-level collective agreement and slightly overrepresented in the Walloon region.

\section{Results}

\subsection{Benchmark estimates}

Table 2 presents OLS estimates of equations (1) to (3). The regression coefficient associated to FTCs in the productivity equation (column 1) is significantly positive at the one percent level and suggests that hourly productivity increases on average by $0.19 \%$ if the share of FTCs increases by 1 percentage point $(0.193 * 0.01=0.00193=0.193 \%)$. The FTC coefficient in the labour cost regression (column 2) also yields a positive estimate at the same significance level suggesting that a 1 percentage point increase in FTCs is associated with a $0.12 \%$ increase in hourly wage costs. The coefficient in column 3 suggests that firms' profitability is positively and significantly (at the five percent level) associated with the share of fixed-term workers: productivity gains induced by FTCs are found to exceed the corresponding wage cost increase.

[Insert Table 2 here]

As argued above, however, OLS estimates should be considered with caution due to potential biases regarding firm-level fixed effects, endogeneity and state dependency. To account for these issues, our 
benchmark equations have been re-estimated with a dynamic GMM-SYS estimator. Estimates are reported in Table 3. ${ }^{\text {vvi }}$ To assess their reliability we applied Hansen and Arellano-Bond tests. For all regressions, we do not reject respectively the null hypotheses of valid instruments ${ }^{\text {xvii }}$ and of no second order auto-correlation in the first-differenced errors. We also estimated additional GMM-SYS models using contemporaneous explanatory variables, but these fail to pass the Hansen and Arellano-Bond tests. This suggests that our approach of using explanatory variables from October in year $t-1$ and dependent variables from year $t$ is warranted (see explanation on the temporality of the variables in Section 4).

Contrary to the OLS estimates, GMM-SYS results suggest that changes in the shares of FTC workers are not significantly related to productivity, wage costs or profits. Note that the disappearance of the significant FTC effects seems to be related to the presence of unobservable time-invariant firm-level heterogeneity rather than to the instrumentation in the GMM estimator: indeed, FTC coefficients estimates in a fixed-effects model without instruments (available upon request) are already insignificant.

\author{
[Insert Table 3 here]
}

\title{
5.2. Sector-specific estimates
}

In this section we present estimates that account for potential heterogeneity of the impact of FTCs across different sectors of activity. Separate GMM-SYS coefficients for industry and services are reported in Table $4 .{ }^{\text {xvii }}$ While the coefficients for the sample of industrial firms remain statistically insignificant, GMM-SYS coefficients for the sample of firms in the service sector suggest a positive relationship between FTCs and hourly productivity that is statistically significant at the ten percent level: a one percentage point increase in the share of FTCs is on average associated with a $0.28 \%$ rise in hourly value added. The difference in productivity effects between the two subsamples of manufacturing and services is statistically significant. The impact of temporary jobs on labour costs and profits is also found to be positive albeit not statistically significant at conventional probability levels.

\section{[Insert Table 4 here]}

The distinction between industry and services is of course relatively crude since it masks potential variations within each of these two macro-sectors. To refine the analysis, we have estimated separate 
regressions for more detailed sectors, namely NACE codes C and D (i.e. mining, quarrying and manufacturing), F (construction), I and J (Financial intermediation; Transport, storage and communications), and G, $\mathrm{H}$ and $\mathrm{K}$ (Wholesale and retail trade, repair of motor vehicles, motorcycles and household goods; Hotels and restaurants; and Real estate, renting and business activities). ${ }^{\text {xix }}$ These categories arguably reflect fundamental differences in production processes as well as variations in the labour intensity, the level of collective bargaining and propensity to use FTCs (cf. Table 5), while at the same time allowing for sufficiently large subsamples required for the estimation of GMM-SYS coefficients.

[Insert Table 5 here]

The regression results for these sub-sectors confirm the absence of a sizable FTC impact in industrial firms: the coefficients in both NACE C-D and NACE F sectors are not significantly different from zero. $^{\mathrm{xx}}$ This is also the case for the service sectors NACE I-J (see Table 6) but not for the service sectors G-H-K. Indeed, GMM-SYS estimates suggest that FTCs in the latter services sectors enhance productivity at the ten percent significance level, have no significant effect on labour costs, and consequently improve firms' profitability (also at the ten percent significance level): a one percentage point increase in the share of FTCs is associated with a $0.48 \%$ rise in the gap between hourly productivity and wage costs (see Table 6).

[Insert Table 6 here]

Given that the time period of our sample includes one of the strongest recessions (i.e. the financial crisis and its aftermath), we have tested the robustness of our results to conjunctural fluctuations. Results in regressions excluding the late 2000s from our sample (available on request) confirm the positive role of FTCs in the G-H-K service sectors; they even suggest a small positive effect on productivity for the entire economy and, in one specification, in the manufacturing sector. This could suggest that any productivity-enhancing effects of FTCs are stronger in periods of economic expansion (when more FTCs are likely to be hired to absorb surges in demand) than in periods of recessions (when FTCs are not renewed). 


\section{Discussion}

The difference between our OLS and GMM-SYS results suggests that the significant FTC effects based on the OLS estimator are probably biased. Especially the observation of a positive relationship between wage costs and temporary employment is suspicious and likely to be driven by business-cycle effects (the share of FTCs is typically procyclical). We therefore focus in this section on the discussion of the GMM-SYS estimator that is not subject to this bias. Applied to the entire sample of firms, the latter provides a sobering message for advocates of temporary employments: over the period covered by our sample (1999-2010), FTCs do not appear to have a significant effect on productivity, wages or profits for the economy as a whole.

A closer look at different sectors, however, reveals a more nuanced picture. Our results suggest that the different productivity-enhancing effects of temporary employment we reviewed in Section 2 appear to be clustered in the service sector. This corroborates previous evidence from country studies by Nielen and Schiersch (2012) who do not find significant FTC effects in German manufacturing and by Leclair and Roux (2007) who document positive productivity effects in French services. Our GMM-SYS results contradict the earlier cross-country study with data from 1995-2005 by Damiani and Pompei (2010) that reached the opposite conclusion, i.e. a negative productivity impact of temporary employment in labour intensive services. As a consequence, the observed productivity-enhancing effect in the service sectors is not captured in studies covering a panel of countries but is in line with existing country-specific evidence.

We interpret our results as evidence that some of the productivity-enhancing mechanisms associated with temporary employment are more salient in service firms than in manufacturing firms. This being said, it should be noted that estimating our equations for sub-samples necessarily reduces the sample size in each regression; it is also to be expected that some coefficients turn out to be significant for specific subsamples if regressions are run on a large variety of subsectors. While we tried to limit the risk of such spurious significance by splitting the entire sample in a limited number of subsamples, further evidence with estimates from other data sources or countries is needed to corroborate our findings. 
If we accept the validity of our results, one way to interpret them is to note that the manufacturing and service sectors differ with respect to various factors of which three can be highlighted in particular: collective bargaining strength, product demand fluctuations and labour intensity.

First, the entire service sector in general and the sectors G-H-K in particular differ from the rest of the economy in that they are characterised by relatively weak collective bargaining. While 33\% of workers in mining and manufacturing benefit from firm-level renegotiations of wages agreed at sectoral or national level, this proportion is only $16 \%$ in the service sectors G-H-K (cf. Table 5). This could help explaining why the productivity gains from FTCs in services suggested by the sector-level regressions (cf. Tables 4 and 6) are not echoed by a similar increase in wages. In other words, the significantly higher profits from FTC employment in wholesale/retail, hotels/restaurants and real estate/renting/business activities could reflect the inability of unions to negotiate firm-level wage increases that are much more common in other parts of the economy.

Second, another consequential difference between services and manufacturing is the capacity to produce stocks that allow to respond to product demand fluctuations: FTCs in services might indeed play an analogous role to product stocks in manufacturing and help businesses to get a better match for fluctuations in demand, which should translate into a higher hourly productivity (Specchia and Vandenberghe 2013). Leclair and Roux (2007) have identified another difference between manufacturing and service activities that could reinforce this effect, namely that many workplaces in service activities are increasingly designed for short-term staff and do not require elaborate on-the-job training - contrary to more and more workplaces in manufacturing where increasingly sophisticated machinery requires intensive training that makes longer employment relations more plausible. Indeed, previous research suggests that demand fluctuations appear to be more pronounced in services than in manufacturing (Davis and Haltiwanger 1999; Van der Linden 1999). Our regression results based on detailed sectors provide further evidence for this interpretation. Additional descriptive statistics presented in Table 5 show the coefficient of variation of output, a variable that can be interpreted as a measure of product demand fluctuation at sector level. We find that variation is relatively low in manufacturing compared to service sectors. The sectors G-H-K, in which positive productivity effects and additional profits from FTCs seemed to be clustered, have a high coefficient of variation of 0.422 (compared to 0.178 for manufacturing and mining) and are therefore arguably more likely to benefit from more flexible work arrangements than other sectors. 
Third, the observed differences between services and manufacturing could be driven by the relatively higher labour intensity in the former. Indeed, as FTCs are a tool for the flexibilization of labour it should have a higher incidence in parts of the economy in which labour plays a relatively more central role in production processes than capital. Our regression analysis allows to pinpoint the productivityenhancing effect of temporary employments in sectors G-H-K (dominated by retail, hotels and restaurants and business services), activities that are more labour intensive than the sectors I-J (financial intermediation, transport, storage and communication): the average share of labour costs in total value added equals $39.4 \%$ in the sectors G-H-K compared to 37\% in I-J (see Table 5). Both of these service sectors are characterised by higher labour intensity than the mining and manufacturing sectors C-D for which we find no significant effect of FTCs. As a consequence, our results do not contradict the idea that labour intensity increases the effect of FTCs and that the observed differences in productivity, wage and profit coefficients between sectors can be partly explained with differences in labour intensity.

We think that it is plausible that all three factors mentioned above - i.e. collective bargaining, product demand fluctuations and labour intensity - can be related to the effect of FTCs. This being said, the aim of this paper was not to isolate each of these factors. For the case of product demand fluctuations, for instance, this is particularly difficult as it is typically measured as a summary statistic of variation over time which means that the moderating role of this variable cannot be consistently estimated in the panel regression framework we adopted in this paper (using the coefficient of variation of output per worker in each firm, for instance, yields only one observation per firm for the entire period of observation). But while it is difficult to isolate the effect of each of these factors on the FTC-productivity-wage nexus, we argue that sectors of activities can be considered as combinations of these factors that together produce differences between manufacturing and services with respect to the consequences of FTCs. We see our results as evidence that sectors are relevant aggregates to study differences in FTC effects and suggest plausible interpretations of the factors that could have brought these differences about; future research could focus on the issue of the relative importance of these different factors.

It is possible that the specificities of the Belgian economy have played in favour of a productivityenhancing effect in the service sector. FTC workers are different from temporary agency workers in that the former are directly hired by the firms that use them in production processes, whereas the latter are employed by an external agency. It is therefore not uncommon that temporary agency workers have permanent contracts with the agency that employs them. So far, FTC have been a common form of labour flexibilisation in Belgium: at the end of the employment period, FTCs allow firms to reassess 
the employment relationship with individual workers and can terminate them if they wish to do so at very low costs compared to PCs. Even before the end of term, severance pay and notice periods for FTCs are much lower compared to standard employment contracts and therefore provide for additional flexibility.

As stated above, labour legislation in Belgium has tried to limit the period of time in which employees can be hired on successive FTCs; more generally, the social partners have so far been able to maintain PCs as the default employment contract. Compared to the European average, over the last 15 years the share of FTCs has been 4-6 percentage points lower in Belgium. It is possible that the Belgian employers who deviate from the default arrangement of PCs do so because they expect high productivity gains from FTCs. This is potentially different in countries like The Netherlands, Poland, Spain or Portugal in which FTCs are more widespread and PCs not as much of a standard arrangement. In light of the U-shaped relationship between employment protection legislation and economic growth tested by Belot et al. (2007), the relatively low FTC rates in Belgium could reflect that non-standard contracts are indeed used by (service sector) employers to buffer against demand fluctuations and that the Belgian employment protection has avoided their widespread use as a means to cut labour costs without enhancing productivity.

Turning to our results for the wage and profit equations, we observe no deviation between productivity and wages in manufacturing, but significant underpayment in service sectors G-H-K. The contrasting results for manufacturing and services with respect to the wage discrimination against temporary workers fits with the observation of lower collective bargaining power in the service sector, where higher turn-over and lower unionisation might induce temporary workers to accept harder jobs and wages below productivity (Manning 2003). This explanation is especially plausible in a country like Belgium where collective bargaining and trade union monitoring of firm-level profits is stronger in blue-collar manufacturing than in services (Garnero et al 2014b).

Finally, the finding that FTCs are only positively related to profits in certain service activities sits well with the observed distribution of temporary employments in the economy: sectors G-H-K, for which our estimates suggest relatively high rents, make considerably more use of FTCs than the rest of the economy (see Table 5) - this could reflect a rational behaviour of profit-maximising firms. The rents are derived from paying FTC workers below their marginal products. 
To be sure, the existence of positive rents also suggests that some firms within $G, H, K$ industries use FTCs sub-optimally. This could be due to imperfect information about the actual productivity effects of FTCs, a plausible assumption given the difficulties associated with measuring productivity. Some larger firms in the G-H-K sectors might also find their ability to extract rents limited by collective bargaining or because they experience lower product demand fluctuation or labour intensity than the average firm in this sector. These explanations should be considered as avenues for future research.

\section{Conclusion}

After having increased in the 1980s and 1990s in most OECD countries, the average share of temporary employments has stagnated in the 2000s and even decreased in a series of countries (including Belgium). A second observation is that within individual OECD countries fixed-term contracts have on average made more inroads in services than in manufacturing. These developments raise three related questions that are addressed frontally in this paper and that concern respectively the effects of temporary employments on a) labour productivity; b) labour costs and c) firm profits.

This paper is one of the first to shed light on all three questions while taking into account differences in the production processes across sectors and subsectors. To do so, we use a large representative matched employer-employee panel dataset for Belgium covering all years between 1999 and 2010. We implement a dynamic system GMM estimator enabling us to address important methodological issues, often neglected in previous studies, such as firm-level time-invariant heterogeneity, endogeneity and state dependence. For the economy as a whole, we find no significant effect of fixed-term employment on firm competitiveness.

Our results suggest that the observed stagnation of temporary employments, or even decline in countries like Belgium, could reflect profit-maximising behaviour of firms: for the economy as a whole, we find no significant evidence for an effect of a firm's use of temporary employments on its average labour productivity or labour costs. Instead of delivering productivity-enhancing flexibility as expected by many policy makers in the 1990s, having a larger share of the workforce on temporary employments does not appear to have a sizeable impact for the average firm. 
However, the paper also provides empirical evidence for the dangers of reasoning in terms of the average firm. The latter of course does not exist as each organisation differs in terms of its historical development, current composition and future growth potential. Many of the theoretical arguments against and in favour of temporary employment tend to be linked to specific aspects of a firm's production process, such as its capacity of creating stocks to absorb fluctuations in product demand, the length of necessary on-the-job training or the possibility to screen new employees for talent and motivation. The sectoral differences in the incidence of temporary employment suggest that some of these factors are clustered within certain sectors of activities. Similarly to Leclair and Roux (2007), our estimation results indeed suggest that productivity-enhancing effects can be observed in the service sector. Moreover, our evidence suggests that the heterogeneous effects of temporary employments are due to differences in production processes: positive productivity effects and firm rents are concentrated in subsectors that are more labour intensive, use less sophisticated technology and are less able to create stocks, as is the case in NACE sectors G-H-K dominated by retail, hotel and restaurants and business services. These sectors also display the highest incidence of temporary employments in Belgium.

\section{References}

Arellano, M. and Bond, O. (1991). 'Some tests of specification for panel data. Monte Carlo evidence and an applicatoin to employment equations', Review of Economic Studies, 58: 277-297.

Arellano, M. and Bover, O. (1995). 'Another look at the instrumental variable estimation of errorcomponent models', Journal of Econometrics, 68: 28-51.

Arulampalam, W. and Booth, A. (1998). 'Training and labour market flexibility: Is there a trade off?', British Journal of Industrial Relations, 36: 521-536.

Baily, M., Hulten, C. and Campbell, D. (1992). 'The distribution of productivity in manufacturing plants’, Brooking Papers on Economic Activity: Microeconomics, 187-249.

Bartelsman, E. and Doms, M. (2000). 'Understanding productivity: Lessons from longitudinal microdata’, Quarterly Journal of Economics, 122: 1721-1758.

Bartelsman, E. and Dhrynes, P. (1988). 'Productivity dynamics: US manufacturing plants 1972-1986', Journal of Productivity Analysis, 9: 5-34.

Bartolucci, C. (2014). 'Understanding the native-immigrant wage gap using matched employeremployee data evidence from Germany', ILR Review, 67: 1166-1202. 
Bassanini, A., Booth A., Brunello, G., De Paola, M. and Leuven, E. (2007). 'Workplace training in Europe', in G. Brunello, P. Garibaldi, E.Wasmer (Eds.), Education and training in Europe. Oxford: Oxford University Press, 143-309.

Becker, G. (1975). Human Capital: A Theoretical and Empirical Analysis, with Special Reference to Education, University of Chicago Press, Chicago.

Belot, M., Boone, J., and Van Ours, J. (2007). 'Welfare-Improving Employment Protection', Economica, 74: 381-396.

Bentolila, S. and Bertola, G. (1990), 'Firing costs and labour demand: How bad is Eurosclerosis?', Review of Economic Studies, 57: 381-402.

Blundell, R. and Bond, S. (1998). 'Initial conditions and moment restrictions in dynamic panel data models', Journal of Econometrics, 87: 115-143.

Boeri, T. (2011). 'Institutional reforms and dualism in European labor markets', in O. Ashenfelter, D. Card (Eds.), Handbook of labor economics, Amsterdam and New York: Elsevier, pp. 1173-1236.

Bond, S. (2002). 'Dynamic panel data models: A guide to micro data methods and practice', Portuguese Economic Journal, 1: 141-162.

Bond, S. and Söderbom, M. (2005). 'Adjustment costs and the identification of Cobb Douglas production functions', IFS Working Paper, No. 05/04, London.

Booth, A., Francesconi, M. and Frank, J. (2002). 'Temporary jobs: Stepping stones or dead ends?', Economic Journal, 112: F189-F213.

Bosio, G. (2014). 'The implications of temporary jobs on the distribution of wages in Italy: an unconditional IVQTE approach', Labour, 28: 64-86.

Bou, J. and Satorra, A. (2007). 'The persistence of abnormal returns at industry and firm levels: Evidence from Spain', Strategic Management Journal, 28: 707-722.

Brown, S. and Sessions, J. (2003). 'Earnings, education, and fixed-term contracts', Scottish Journal of Political Economy, 50: 492-506.

Cappellari, L., Dell’Aringa, C. and Leonardi, L. (2012). 'Temporary employment, job flows, and productivity: A tale of two reforms’, Economic Journal, 122: F188-F215.

Comi, S. and Grasseni, M. (2012). 'Are temporary workers discriminated against? Evidence from Europe', Manchester School, 80: 28-50.

Damiani, M. and Pompei, F. (2010). 'Labour protection and productivity in EU economies: 1995-2005', European Journal of Comparative Economics, 7 (2): 373-411.

Davis, S. and Haltiwanger, J. (1999). 'Gross job flows', in Ashenfelter, O. and Card, D. (eds.), Handbook of Labor Economics, Elsevier, Amsterdam. 
De la Rica, S. (2004). 'Wage gaps between workers with indefinite and fixed-term contracts: The impact of firm and occupational segregation’, Moneda y Crédito, 219: 43-69.

Demunter, C. (2000). 'Structure and Distribution of Earnings Survey: Analysis 1995’, Working Paper. Brussels: Statistics Belgium.

Dhyne, E. and Mahy, B. (2012), 'Work organization, labour contracts and employment', International Journal of Manpower, 33: 246-263.

Dhyne, E. and Mahy, B. (2009). 'The use of fixed-term contracts and the labour adjustment in Belgium’, NBB Working Paper, No. 169, Brussels.

Dolado, J. and Stucchi, R. (2008). 'Do temporary contracts affect total factor productivity?: Evidence from Spanish manufacturing firms’, IZA Discussion Paper, No. 3832, Bonn.

du Caju, P., Rycx, F. and Tojerow, I. (2011). 'Inter-industry wage differentials: How much does rentsharing matter?’, Manchester School, 79: 691-717.

du Caju, P., Rycx, F. and Tojerow, I. (2012). 'Wage structure effects of international trade in a small open economy: The case of Belgium', Review of World Economics, 148: 297-331.

Engellandt, A. and Riphahn, R. (2005). 'Temporary contracts and employee effort', Labour Economics, 12: 281-299.

Eurostat (2012). Labour force survey, Luxembourg.

Fouarge, D., de Grip, A., Smits, W. and de Vries, R. (2012). 'Flexible contracts and human capital investments', De Economist, 16: 177-195.

Garnero, A., S. Kampelmann and F. Rycx (2014a). 'The Heterogeneous Effects of Workplace Diversity on Productivity, Wages and Profits', Industrial Relations: A Journal of Economy and Society, vol. 53: 430-477.

Garnero, A., S. Kampelmann and F. Rycx (2014b). 'Part-time Work, Wages and Productivity: Evidence from Belgian Matched Panel Data’, Industrial and Labor Relations Review, 67: 926-954.

Geroski, P. and Jacquemin, A. (1988). ‘The persistence of profits: A European comparison', Economic Journal, 98: 375-389.

Göbel, C. and Zwick, T. (2012). 'Age and productivity: Sector differences’, De Economist, 160: 35-57.

Göbel, C. and Zwick, T. (2013), 'Are personnel measures effective in increasing productivity of old workers?', Labour Economics, 22: 80-93.

Hansen, Lars P (1982). 'Large Sample Properties of Generalized Method of Moments Estimators', Econometrica, 50: 1029-1054.

Heery, E. (2004). 'The trade union response to agency labour in Britain', Industrial Relations Journal, 35: 434-450. 
Hellerstein, J. and Neumark, D. (2004). 'Production function and wage equation estimation with heterogeneous labor: Evidence from a new matched employer-employee data set', NBER Working Paper, No. 10365, Cambridge (Мa.).

Hellerstein, J. and Neumark, D. (1995). 'Are earning profiles steeper than productivity profiles? Evidence from Israeli firm data’, Journal of Human Resources, 30: 89-112.

Hellerstein, J., Neumark, D. and Troske, K. (1999). 'Wages, productivity and worker characteristics: Evidence from plant-level production functions and wage equations', Journal of Labor Economics, 17: 409-446.

Hempell, T. (2005). 'What's spurious? What's real? Measuring productivity impacts of ICT at the firm level', Empirical Economics, 30:427-464.

Houseman, S. (2001). 'Why employers use flexible staffing arrangements: Evidence from an establishment survey’, Industrial and Labor Relations Review, 55: 149-170.

Jahn, E., Riphahn, R. and Schnabel, C. (2012). 'Flexible forms of employment: Boon and bane', Economic Journal, 122: F115-F124.

Jimeno, J. and Toharia, L. (1993). 'The effects of fixed-term employment on wages: Theory and evidence from Spain’, Investigaciones Economicas, 17: 475-494.

Kampelmann, S. and Rycx, F. (2012). 'Are Occupations Paid What They Are Worth? An Econometric Study of Occupational Wage Inequality and Productivity’, De Economist, 160:. 257-287.

Lazear, E. and Rosen S. (1981). 'Rank-order tournaments as optimum labor contracts', Journal of Political Economy, 89: 841-864.

Le Bihan, H., Montornès, J., and Heckel, T. (2012). 'Sticky wages: evidence from quarterly microeconomic data', American Economic Journal: Macroeconomics, 4: 1-32.

Leclair M. and Roux, S. (2007). 'Productivité relative et utilisation des emplois de courte durée dans les entreprises’, Economie et Statistique, 405-406: 47-76.

Lindbeck, A. and Snower, J. (1986). 'Wage setting, unemployment and insider-outsider relations', American Economic Review, 76: 235-239.

Mahhlberg, B., Freund, I., Cuaresma J. and Prskawets, A. (2013). ‘Ageing productivity and wages in Austria', Labour Economics, 22: 5-15.

Mahy, B. (2005). 'Flexibilité des contrats et demande de travail en Belgique', Reflets et Perspectives de la vie économique, XLIV: 25-35.

Mahy, B., Rycx F. and Vermeylen, G. (2015). 'Educational mismatch and firm productivity: Do skills, technology and uncertainty matter?', De Economist, 163: 233-262.

Manning, A. (2003)' Monopsony in motion: Imperfect competition in labor markets, Princeton: Princeton University Press. 
McGahan, A. and Porter, M. (1999). 'The persistence of shocks to profitability', Review of Economics and Statistics, 81: 143-153.

McMillan, D. and Wohar, M. (2011). 'Profit-persistence revisited: The case of the UK', Manchester School, 79: 510-527.

Mueller, D. (1977). 'The persistence of profits above the norm', Economica, 44: 369-380.

Nielen, S. and Schiersch, A. (2012). 'Productivity in German manufacturing firms: Does fixed-term employment matter?', Schumpeter Discussion Paper, No. 4, University of Wuppertal, Germany.

Nielen, S. and Schiersch, A. (2014). 'Temporary agency work and firm competitiveness: Evidence from German manufacturing firm’, Industrial Relations, 53: 365-393.

Nunziata, L. and Staffolani, S. (2007). 'Short-term contracts regulations and dynamic labour demand: Theory and evidence', Scottish Journal of Political Economy, 54: 72-104.

OECD (2002). 'Taking the measure of temporary employment', In: OECD Employment Outlook, Paris: OECD Publishing.

OECD (2009). Measuring Capital, Paris: OECD Publishing.

OECD (2015). Dataset 'LFS - Employment by Permanency'. Retrieved on March 30 2015. URL: http://stats.oecd.org/Index.aspx?DataSetCode=TEMP_I

Oi, W. (1962). 'Labor as a quasi-fixed factor', Journal of Political Economy, 70: 538-555.

Piore, M. (1978). 'Dualism in the labour market: A response to uncertainty and flux, the case of France', Revue économique, 19: 26-37.

Roodman, D. (2009). 'A Note on the Theme of Too Many Instruments', Oxford Bulletin of Economics and Statistics, 71: 135-58.

Riley, N. (1997). 'Determinants of union membership: a review’, Labour, 11:265-301.

Salvatori, A. (2009). 'What do unions do to temporary employment?', IZA Discussion Paper, No. 4554, Bonn.

Shepherd, W. (1975). The treatment of market power, New York: Columbia University Press.

Specchia, G.L. and Vandenberghe, V. (2013). 'Is part-time employment a boon or bane for firm productivity?’, mimeo, IRES, Université catholique de Louvain.

Syverson, C. (2011). 'What determines productivity?', Journal of Economic Literature, 49: 326-365.

Teulings, C. and Hartog, J. (1998). Corporatism or Competition? Labour Contracts, Institutions and Wage Structures in International Comparison. Cambridge: Cambridge University Press.

Van der Linden (1999). 'Rotation des emplois et mobilité des travailleurs en Belgique', Brussels Economic Review, 162: 107-148.

van Ours, J. and Stoeldraijer, L. (2011). 'Age, wage and productivity in Dutch manufacturing’, De Economist, 159: 113-137. 
Vidal, M. and Tigges, L. (2009). 'Temporary employment and strategic staffing in the manufacturing sector', Industrial Relations, 48: 55-72. 
Table 1: Selected descriptive statistics at the firm and worker level (Mean values 1999-2010)

\begin{tabular}{|c|c|c|c|c|}
\hline Variables & $\begin{array}{c}\text { Firm level } \\
(1) \\
\end{array}$ & & $\begin{array}{c}\text { Worker lev } \\
(2) \\
\end{array}$ & \\
\hline & & Total & $\begin{array}{l}\text { Permanent } \\
\text { jobs }\end{array}$ & $\begin{array}{c}\text { Fixed-term } \\
\text { jobs }\end{array}$ \\
\hline Hourly value-added $\left(€^{\mathrm{a}}\right)$ & 66.19 & 64.34 & 65.25 & 53.33 \\
\hline Hourly wage cost $\left(€^{\mathrm{a}}\right)$ & 33.34 & 30.67 & 31.15 & 26.90 \\
\hline $\begin{array}{l}\text { Hourly gross profit }\left(€^{\mathrm{a}}\right) \text {, i.e. value added per } \\
\text { hour - wage cost per hour }\end{array}$ & 32.85 & 33.68 & 34.10 & 26.43 \\
\hline Permanent contracts (\%) & 0.96 & 0.95 & 1.00 & 0.00 \\
\hline Fixed-term employment contracts (\%) & 0.03 & 0.04 & 0.00 & 1.00 \\
\hline Other contracts (mostly apprentices) (\%) & 0.01 & 0.01 & 0.00 & 0.00 \\
\hline Primary or lower secondary education (\%) & 0.30 & 0.30 & 0.29 & 0.37 \\
\hline Upper secondary education (\%) & 0.43 & 0.44 & 0.43 & 0.48 \\
\hline Higher education (\%) & 0.27 & 0.27 & 0.27 & 0.15 \\
\hline Workers with 10 years of tenure or more (\%) & 0.40 & 0.42 & 0.43 & 0.03 \\
\hline Share of workers $<30$ years & 0.21 & 0.22 & 0.20 & 0.58 \\
\hline Share of workers $>49$ years & 0.18 & 0.18 & 0.19 & 0.06 \\
\hline Women (\%) & 0.27 & 0.30 & 0.29 & 0.40 \\
\hline Part-time (less than 30 hours per week, \%) & 0.16 & 0.18 & 0.17 & 0.34 \\
\hline Blue-collar workers (\%) & 0.55 & 0.51 & 0.51 & 0.60 \\
\hline Mining and quarrying $(\mathrm{C})$ & 0.01 & 0.01 & 0.01 & 0.01 \\
\hline Manufacturing (D) & 0.58 & 0.54 & 0.55 & 0.44 \\
\hline Electricity, gas and water supply (E) & 0.00 & 0.02 & 0.02 & 0.02 \\
\hline Construction $(F)$ & 0.10 & 0.07 & 0.07 & 0.01 \\
\hline $\begin{array}{l}\text { Wholesale and retail trade, repair of motor } \\
\text { vehicles, motorcycles and personal and } \\
\text { household goods }(G)\end{array}$ & 0.12 & 0.15 & 0.15 & 0.18 \\
\hline Hotels and restaurant $(\mathrm{H})$ & 0.01 & 0.02 & 0.02 & 0.02 \\
\hline Transport, storage and communication (I) & 0.06 & 0.06 & 0.06 & 0.04 \\
\hline Financial intermediation $(\mathrm{J})$ & 0.02 & 0.01 & 0.02 & 0.00 \\
\hline Real estate, renting and business activities (K) & 0.10 & 0.12 & 0.11 & 0.27 \\
\hline $\begin{array}{l}\text { Size of the firm (number of full-time equivalent } \\
\text { workers) }\end{array}$ & 306.36 & 504.9 & 502.7 & 495.9 \\
\hline Firm-level collective agreement (\%) & 0.32 & 0.38 & 0.38 & 0.35 \\
\hline Brussels & 0.15 & 0.15 & 0.15 & 0.14 \\
\hline Flanders & 0.57 & 0.60 & 0.60 & 0.57 \\
\hline Wallonia & 0.28 & 0.25 & 0.25 & 0.29 \\
\hline Number of individual observations & & 248,648 & 234,199 & 10,866 \\
\hline Distribution in \% & & $100^{\mathrm{b}}$ & 94.2 & 4.4 \\
\hline Number of firm-year observations & 6,713 & & & \\
\hline
\end{tabular}

Notes: Column (1) shows descriptive statistics relative to data aggregated at the firm level, while column (2) shows aggregates at the worker level. ${ }^{a}$ At 2004 constant prices. Own calculations based on SES-SBS data. ${ }^{\text {b }}$ The sum of the observations relative to permanent and fixed-term workers is not equal to the total number of observations in the sample. The remaining share of observations, 1.4 percent, refers to other contracts (mostly apprentices). 
Table 2: Entire sample, OLS estimates

\begin{tabular}{|c|c|c|c|}
\hline Dependent variables: & $\begin{array}{c}\text { Value added per hour } \\
\text { worked (ln) } \\
(1)\end{array}$ & $\begin{array}{l}\text { Wage cost per hour } \\
\text { worked (ln) } \\
(2) \\
\end{array}$ & $\begin{array}{l}\text { Profit per hour } \\
\text { worked (ln) }^{c} \\
\text { (3) }\end{array}$ \\
\hline Intercept & $\begin{array}{c}2.184^{* * *} \\
(0.078)\end{array}$ & $\begin{array}{c}2.820^{* * *} \\
(0.040)\end{array}$ & $\begin{array}{c}-1.138^{* * *} \\
(0.172)\end{array}$ \\
\hline Fixed-term contracts & $\begin{array}{c}0.193 * * * \\
(0.056)\end{array}$ & $\begin{array}{c}0.117 * * * \\
(0.041)\end{array}$ & $\begin{array}{c}0.274 * * \\
(0.132)\end{array}$ \\
\hline Apprentices & $\begin{array}{l}-0.774 \\
(0.736)\end{array}$ & $\begin{array}{c}-0.871 * * \\
(0.347)\end{array}$ & $\begin{array}{l}-0.774 \\
(0.736)\end{array}$ \\
\hline Temporary agency workers & $\begin{array}{l}-0.214^{*} \\
(0.127)\end{array}$ & $\begin{array}{c}-0.221^{* * *} \\
(0.072)\end{array}$ & $\begin{array}{l}-0.214^{*} \\
(0.127)\end{array}$ \\
\hline Worker characteristics ${ }^{a}$ & Yes & Yes & Yes \\
\hline Firm characteristics ${ }^{\mathrm{b}}$ & Yes & Yes & Yes \\
\hline Year dummies & Yes & Yes & Yes \\
\hline Adjusted R-squared & 0.431 & 0.517 & 0.331 \\
\hline $\begin{array}{l}\text { F-stat (joint significance) } \\
\text { p-value }\end{array}$ & $\begin{array}{c}104.06 \\
0.00\end{array}$ & $\begin{array}{c}169.15 \\
0.00\end{array}$ & $\begin{array}{c}76.03 \\
0.00\end{array}$ \\
\hline $\begin{array}{l}\text { Number of firm-year } \\
\text { observations }\end{array}$ & 6,714 & 6,714 & 6,714 \\
\hline Number of firms & 1,844 & 1,844 & 1,844 \\
\hline
\end{tabular}

Notes: $* * * / * * / *$ significant at $1 \%, 5 \%$, and $10 \%$ level, respectively. Robust standard errors are reported between parentheses.

a Share of the workforce that: (i) has at most lower secondary education and a degree from tertiary education, respectively, (ii) has at least 10 years of tenure, and (iii) is younger than 25 and older than 49 years, respectively, (iv) is female, (v) works part-time, (vi) occupies blue-collar jobs.

${ }^{\mathrm{b}}$ Natural logarithm of firm size (i.e. number of full-time equivalent workers), natural logarithm of capital stock per worker, the level of collective wage bargaining (1 dummy), sectoral affiliation (8 dummies) and the region where the firm is located (2 dummies).

${ }^{\mathrm{c}} \ln$ (profit per hour worked) = $\ln$ (value added per hour worked - wage cost per hour worker). 


\begin{tabular}{|c|c|c|c|}
\hline & \multicolumn{3}{|c|}{ GMM-SYS $^{d}$} \\
\hline Dependent variables: & $\begin{array}{l}\text { Value added per hour } \\
\text { worked (ln) } \\
(1)\end{array}$ & $\begin{array}{l}\text { Labour cost per } \\
\text { hour worked (ln) } \\
(2)\end{array}$ & $\begin{array}{c}\text { Profit per hour } \\
\text { worked (ln) }^{\mathrm{e}} \\
(3)\end{array}$ \\
\hline Lagged dependent variable (ln) & $\begin{array}{c}0.655^{* * *} \\
(0.057)\end{array}$ & $\begin{array}{c}0.447 * * * \\
(0.135)\end{array}$ & $\begin{array}{c}0.539^{* * *} \\
(0.047)\end{array}$ \\
\hline Fixed-term contracts & $\begin{array}{c}0.061 \\
(0.052)\end{array}$ & $\begin{array}{l}-0.027 \\
(0.038)\end{array}$ & $\begin{array}{c}0.156 \\
(0.189)\end{array}$ \\
\hline Apprentices & $\begin{array}{c}-1.028^{* *} \\
(0.461)\end{array}$ & $\begin{array}{c}-0.748 * * \\
(0.351)\end{array}$ & $\begin{array}{l}-1.434 \\
(1.868)\end{array}$ \\
\hline Temporary agency workers & $\begin{array}{l}-0.042 \\
(0.075)\end{array}$ & $\begin{array}{c}-0.133^{* *} \\
(0.058)\end{array}$ & $\begin{array}{c}0.221 \\
(0.359)\end{array}$ \\
\hline Worker characteristics ${ }^{a}$ & Yes & Yes & Yes \\
\hline Firm characteristics $^{\mathrm{b}}$ & Yes & Yes & Yes \\
\hline Year dummies & Yes & Yes & Yes \\
\hline Hansen J statistic & 620.0 & 639.2 & 586.91 \\
\hline p-value & 0.27 & 0.12 & 0.63 \\
\hline Arellano-Bond statistic (AR2) ${ }^{c}$ & 1.52 & 0.94 & 1.30 \\
\hline p-value & 0.13 & 0.35 & 0.14 \\
\hline Number of firm-year observations & 6,714 & 6,714 & 6,714 \\
\hline Number of firms & 1,844 & 1,844 & 1,844 \\
\hline
\end{tabular}

Notes: $* * * / * * / *$ significant at $1 \%, 5 \%$, and $10 \%$ level, respectively. Robust standard errors are reported between parentheses.

${ }^{\text {a }}$ Share of the workforce that: (i) has at most lower secondary education and a degree from tertiary education, respectively, (ii) has at least 10 years of tenure, and (iii) is younger than 25 and older than 49 years, respectively, (iv) is female, (v) works part-time, (vi) occupies blue-collar jobs.

${ }^{\mathrm{b}}$ Natural logarithm of firm size (i.e. number of full-time equivalent workers), natural logarithm of capital stock per worker, the level of collective wage bargaining (1 dummy), sectoral affiliation (8 dummies) and the region where the firm is located (2 dummies).

'AR2 displays the test for second-order autocorrelation in the first-differenced errors.

${ }^{\mathrm{d}}$ First and second lags of explanatory variables, excluding time dummies, are used as instruments.

${ }^{\mathrm{e}} \ln ($ profit per hour worked) $=\ln$ (value added per hour worked - wage cost per hour worker). 
Table 4: Industry (NACE codes C to F) vs. Services (NACE codes G to K), GMM-SYS estimates

\begin{tabular}{|c|c|c|c|c|c|c|}
\hline \multirow{4}{*}{ Dependent variables: } & \multicolumn{6}{|c|}{ GMM-SYS $^{\mathrm{d}}$} \\
\hline & \multicolumn{2}{|c|}{$\begin{array}{c}\text { Value added } \\
\text { per hour worked (ln) }\end{array}$} & \multicolumn{2}{|c|}{$\begin{array}{c}\text { Wage cost } \\
\text { per hour worked (ln) }\end{array}$} & \multicolumn{2}{|c|}{$\begin{array}{l}\text { Profit per hour } \\
\text { worked (ln) }\end{array}$} \\
\hline & (1) & (2) & (3) & (4) & (5) & (6) \\
\hline & Industry & Services & Industry & Services & Industry & Services \\
\hline \multirow[t]{2}{*}{ Lagged dependent variable (ln) } & $0.641 * * *$ & $0.555 * * *$ & $0.514 * * *$ & $0.374 * * *$ & $0.518^{* * *}$ & $0.524 * * *$ \\
\hline & $(0.043)$ & $(0.122)$ & $(0.107)$ & $(0.177)$ & $(0.050)$ & $(0.071)$ \\
\hline \multirow[t]{2}{*}{ Fixed-term contracts } & 0.067 & $0.276^{*}$ & 0.026 & 0.094 & 0.220 & 0.302 \\
\hline & $(0.070)$ & $(0.164)$ & $(0.038)$ & $(0.123)$ & $(0.514)$ & $(0.540)$ \\
\hline \multirow[t]{2}{*}{ Apprentices } & -0.307 & 3.565 & -0.494 & 1.719 & 4.296 & 6.740 \\
\hline & $(0.431)$ & (3.779) & $(0.373)$ & $(1.759)$ & $(3.283)$ & $(19.696)$ \\
\hline \multirow[t]{2}{*}{ Temporary agency workers } & 0.126 & -0.155 & -0.017 & -0.308 & 0.468 & 1.140 \\
\hline & $(0.192)$ & $(0.368)$ & $(0.101)$ & $(0.360)$ & $(0.807)$ & $(1.852)$ \\
\hline Worker characteristics ${ }^{a}$ & Yes & Yes & Yes & Yes & Yes & Yes \\
\hline Firm characteristics ${ }^{\text {b }}$ & Yes & Yes & Yes & Yes & Yes & Yes \\
\hline Year dummies & Yes & Yes & Yes & Yes & Yes & Yes \\
\hline Hansen J statistic & 503.43 & 336.36 & 502.53 & 338.02 & 499.21 & 260.41 \\
\hline p-value & 0.339 & 0.839 & 0.350 & 0.822 & 0.089 & 0.585 \\
\hline Arellano-Bond statistic $(\mathrm{AR} 2)^{\mathrm{C}}$ & 1.20 & 1.41 & 0.79 & 0.85 & 0.90 & 1.60 \\
\hline p-value & 0.232 & 0.158 & 0.427 & 0.397 & 0.370 & 0.110 \\
\hline $\begin{array}{l}\text { Number of firm-year } \\
\text { observations }\end{array}$ & 4,576 & 2,138 & 4,576 & 2,138 & 4,576 & 2,138 \\
\hline Number of firms & 1,168 & 676 & 1,168 & 676 & 1,168 & 676 \\
\hline
\end{tabular}

Notes: $* * * / * * / *$ significant at $1 \%, 5 \%$, and $10 \%$ level, respectively. Robust standard errors are reported between parentheses.

${ }^{a}$ Share of the workforce that: (i) has at most lower secondary education and a degree from tertiary education, respectively, (ii) has at least 10 years of tenure, and (iii) is younger than 25 and older than 49 years, respectively, (iv) is female, (v) works part-time, and (vi) occupies bluecollar jobs.

${ }^{\mathrm{b}}$ Natural logarithm of firm size (i.e. number of full-time equivalent workers), natural logarithm of capital stock per worker, the level of collective wage bargaining ( 1 dummy), sectoral affiliation and the region where the firm is located (2 dummies).

${ }^{\mathrm{c}} \mathrm{AR} 2$ displays the test for second-order autocorrelation in the first-differenced errors.

${ }^{\mathrm{d}}$ First and second lags of explanatory variables, excluding time dummies, are used as instruments.

${ }^{\mathrm{e}} \ln ($ profit per hour worked $)=\ln ($ value added per hour worked - wage cost per hour worker). 
Table 5: Complementary descriptive statistics by sector (mean values 1999-2010)

\begin{tabular}{|c|c|c|c|c|c|c|}
\hline Sector of activity: & $\begin{array}{l}\text { Number of } \\
\text { employee } \\
\text { observations }\end{array}$ & $\begin{array}{l}\text { Number of } \\
\text { firm } \\
\text { observations }\end{array}$ & $\begin{array}{l}\text { Share of } \\
\text { FTCs (\%) }\end{array}$ & $\begin{array}{l}\text { Labor cost } \\
\text { as \% of } \\
\text { value added }\end{array}$ & $\begin{array}{l}\text { Firm-level } \\
\text { collective } \\
\text { bargaining } \\
\text { coverage } \\
(\%)\end{array}$ & $\begin{array}{l}\text { Coefficient } \\
\text { of variation } \\
\text { of output }\end{array}$ \\
\hline Mining and quarrying (C) & 1,705 & 58 & 4.63 & 28.8 & 30.0 & 0.565 \\
\hline Manufacturing (D) & 133,561 & 3879 & 3.56 & 35.2 & 33.3 & 0.171 \\
\hline Electricity, gas and water supply (E) & 5,390 & 22 & 5.00 & 19.9 & 40.0 & 1.198 \\
\hline Construction (F) & 17,163 & 659 & 0.73 & 39.8 & 5.7 & 0.229 \\
\hline $\begin{array}{l}\text { Wholesale and retail trade, repair of motor } \\
\text { vehicles, motorcycles and personal and } \\
\text { household goods }(G)\end{array}$ & 38,484 & 809 & 5.21 & 36.5 & 18.4 & 0.618 \\
\hline Hotels and restaurant $(\mathrm{H})$ & 3,768 & 97 & 5.87 & 42.0 & 7.1 & 0.306 \\
\hline Transport, storage and communication (I) & 15,571 & 378 & 2.97 & 39.5 & 27.3 & 0.301 \\
\hline Financial intermediation ( $\mathrm{J})$ & 3,597 & 120 & 1.50 & 29.0 & 21.4 & 0.359 \\
\hline Real estate, renting and business activities (K) & 29,445 & 691 & 9.82 & 42.4 & 15.2 & 0.202 \\
\hline $\mathrm{C}+\mathrm{D}$ & 135,266 & 3937 & 3.57 & 35.2 & 33.3 & 0.178 \\
\hline $\mathrm{F}$ & 17,163 & 659 & 0.73 & 39.8 & 5.7 & 0.229 \\
\hline $\mathrm{I}+\mathrm{J}$ & 19,168 & 498 & 2.70 & 37.0 & 26.0 & 0.315 \\
\hline G-H-K & 71,697 & 1597 & 7.14 & 39.4 & 16.3 & 0.422 \\
\hline Total & 248,684 & 6713 & 4.36 & 36.7 & 0.32 & 0.256 \\
\hline
\end{tabular}


Table 6: Wholesale and retail trade, Hotels and restaurants \& Real estate, renting and business activities (NACE codes G, H and K) vs. Financial intermediation \& Transport, storage and communication (NACE codes I and J), GMM-SYS estimates

\begin{tabular}{|c|c|c|c|c|c|c|}
\hline \multirow{3}{*}{ Dependent variables: } & \multicolumn{6}{|c|}{ GMM-SYS $^{d}$} \\
\hline & \multicolumn{2}{|c|}{$\begin{array}{c}\text { Value added } \\
\text { per hour worked (ln) }\end{array}$} & \multicolumn{2}{|c|}{$\begin{array}{c}\text { Wage cost } \\
\text { per hour worked (ln) }\end{array}$} & \multicolumn{2}{|c|}{$\begin{array}{l}\text { Profit per hour } \\
\text { worked (ln) }{ }^{\mathrm{e}}\end{array}$} \\
\hline & (1) & (2) & (3) & (4) & (5) & (6) \\
\hline \multirow[t]{2}{*}{ Lagged dependent variable (ln) } & $0.514^{* * *}$ & $0.903^{* * *}$ & $0.363^{* *}$ & $0.903^{* * *}$ & $0.611^{* * *}$ & $0.731^{* * *}$ \\
\hline & $(0.133)$ & $(0.073)$ & $(0.185)$ & $(0.061)$ & $(0.057)$ & $(0.088)$ \\
\hline \multirow[t]{2}{*}{ Fixed-term contracts } & $0.288^{*}$ & -0.588 & 0.143 & -2.488 & $0.481 *$ & -0.786 \\
\hline & $(0.152)$ & $(0.369)$ & $(0.119)$ & $(0.185)$ & $(0.271)$ & $(1.067)$ \\
\hline Apprentices & $(3.531)$ & $(3.028$ & $(1.687$ & $(2.349$ & $(20.563$ & $(17.060$ \\
\hline \multirow[t]{2}{*}{ Temporary agency workers } & -0.217 & -0.128 & -0.343 & -0.271 & 1.274 & -1.704 \\
\hline & $(0.375$ & $(0.932$ & $(0.332$ & $(0.926$ & $(1.852$ & $(7.219$ \\
\hline Worker characteristics $^{\text {a }}$ & Yes & Yes & Yes & Yes & Yes & Yes \\
\hline Firm characteristics ${ }^{\mathrm{b}}$ & Yes & Yes & Yes & Yes & Yes & Yes \\
\hline Year dummies & Yes & Yes & Yes & Yes & Yes & Yes \\
\hline Hansen J statistic & 331.88 & 107.78 & 302.13 & 77.66 & 282.87 & 76.36 \\
\hline Arellano-Bond statistic (AR2) ${ }^{c}$ & 1.29 & -0.48 & 0.83 & -1.41 & 1.45 & 0.69 \\
\hline $\mathrm{p}$-value & 0.196 & 0.629 & 0.406 & 0.157 & 0.147 & 0.491 \\
\hline Number of firm-year observations & 1,649 & 489 & 1,649 & 489 & 1,649 & 489 \\
\hline Number of firms & 524 & 152 & 524 & 152 & 524 & 152 \\
\hline
\end{tabular}

Notes: $* * * / * * / *$ significant at $1 \%, 5 \%$, and $10 \%$ level, respectively. Robust standard errors are reported between parentheses.

${ }^{a}$ Share of the workforce that: (i) has at most lower secondary education and a degree from tertiary education, respectively, (ii) has at least 10 years of tenure, and

(iii) is younger than 25 and older than 49 years, respectively, (iv) is female, (v) works part-time, and (vi) occupies blue-collar jobs.

${ }^{\mathrm{b}}$ Natural logarithm of firm size (i.e. number of full-time equivalent workers), natural logarithm of capital stock per worker, the level of collective wage bargaining (1 dummy), sectoral affiliation and the region where the firm is located (2 dummies).

${ }^{\mathrm{c}} \mathrm{AR} 2$ displays the test for second-order autocorrelation in the first-differenced errors.

${ }^{\mathrm{d}}$ First and second lags of explanatory variables, excluding time dummies, are used as instruments.

${ }^{\mathrm{e}} \ln ($ profit per hour worked) $=\ln ($ value added per hour worked - wage cost per hour worker) 


\footnotetext{
i The "Directive 1999/70/CE du Conseil du 28 juin 1999 concernant l'accord-cadre CES, UNICE et CEEP sur le travail à durée déterminée."

ii The "Loi du 5 juin 2002 sur le principe de non-discrimination en faveur des travailleurs avec un contrat de travail à durée déterminée, M.B., 26 juin 2002."

iii This is estimated through the 'perpetual inventory method' (or PIM, see e.g. OECD (2009) for more details). Following standard practice, we assume a 5 percent annual rate of depreciation.
}

${ }^{\text {iv }}$ All independent variables with information on the composition of the firm's workforce are measured in terms of shares in total work hours.

${ }^{\mathrm{v}}$ From a theoretical perspective, competitive forces should eliminate abnormal profits (McMillan and Wohar 2011). This said, a large literature, dating back to Shepherd (1975) and Mueller (1977) and taken further by Geroski and Jacquemin (1988), McGahan and Porter (1999), Bou and Satorra (2007) and others, suggests that profit persistence is large and inconsistent with the competitive framework. More recent papers further show that firms with above (below) normal profits have high (low) barriers to entry and exit (McMillan and Wohar 2011). In light of this so-called 'persistence of profits literature', there are strong arguments for modelling profits in a dynamic way, i.e. for including the lagged dependent variable among covariates in Equation (3). The assumption of persistent productivity both at the industry and firm level also finds some support in the literature (see e.g. Baily et al. 1992; Bartelsman and Dhrymes 1988; Bartelsman and Doms 2000). Researchers 'documented, virtually without exception, enormous and persistent measured productivity differences across producers, even within narrowly defined industries' (Syverson 2011: 326). Large parts of these productivity differences are still hard to explain. The persistence of wage costs is also highlighted in the literature (see e.g. du Caju et al. 2011, 2012; Le Bihan et al. 2012). Wage stickiness is notably the outcome of labour market institutions, adjustment costs and efficiency wages' motives.

${ }^{\mathrm{vi}}$ It is standard in the literature to use dynamic panel data methods such as those proposed by Arellano and Bond (1991) to overcome key econometric issues, in particular lag-dependency, firm fixed effects and endogenity of input shares. Accordingly, many recent papers rely on dynamic GMM methods to estimate the impact of workforce characteristics on productivity and/or labour costs (see e.g. Göbel and Zwick 2012, 2013; Kampelman and Rycx 2012; Mahlberg et al. 2013; Mahy et al. 2015; Nielen and Schiersch 2012, 2014).

vii The other potentially endogenous input factors in the model are instrumented in the same way, i.e. levels are instrumented by lagged differences and vice versa.

viii Bond and Söderbom (2005) provide a review of the literature regarding the identification of production functions. The authors notably highlight that adjustment costs of labour and capital can justify the use of lagged values (of endogenous variables) as instruments.

${ }^{\text {ix }}$ Actually our dependent and independent variables are not recorded for the exact same time period with a reasonably close interval. See Section 4.

${ }^{\mathrm{x}}$ We also tested for weak instruments by computing the Kleibergen-Paap rk Wald F statistic (van Ours and Stoeldraijer, 2011). Given that this test is not applicable in a GMM-SYS specification, we used a GMM specification in first differences in which the first-differenced shares of FTCs are instrumented by their lagged levels (in t-1 and t-2). We reject the null hypothsis of weak instruments for all models presented in this paper, including the sector-specific models.

${ }^{\mathrm{xi}}$ It thus covers the following sectors: (i) mining and quarrying (C), (ii) manufacturing (D), (iii) electricity, gas and water supply (E), (iv) construction (F), v) wholesale and retail trade, repair of motor vehicles, motorcycles and personal and household goods (G), (vi) hotels and restaurants (H), (vii) transport, storage and communication (I), (viii) financial intermediation (J), and ix) real estate, renting and business activities (K).

xii The SES is a stratified sample. The stratification criteria refer respectively to the region (NUTS-groups), the principal economic activity (NACE-groups) and the size of the firm. The sample size in each stratum depends on the size of the firm. Sampling percentages of firms are respectively equal to 10,50 and 100 percent when the number of workers is lower than 50, between 50 and 99, and above 100. Within a firm, sampling percentages of employees also depend on size. Sampling percentages of employees reach respectively 100, 50, 25, 14.3 and 10 percent when the number of workers is lower than 20, between 20 and 50, between 50 and 99, between 100 and 199, and between 200 and 299. Firms employing 300 workers or more have to report information for an absolute number of employees. This number ranges between 30 (for firms with between 300 and 349 workers) and 200 (for firms with 12,000 workers or more). To guarantee that firms report information on a representative sample of their workers, they are asked to follow a specific procedure. First, they have to rank their employees in alphabetical order. Next, Statistics Belgium gives them a random letter (e.g. the letter O) from which they have to start when reporting information on their employees (following the alphabetical order of workers' names in their list). If they reach the letter $\mathrm{Z}$ and still have to provide information on some of their employees, they have to continue from the letter A in their list. Moreover, firms that employ different categories of workers, namely managers, blue- and/or whitecollar workers, have to set up a separate alphabetical list for each of these categories and to report information on a number of workers in these different groups that is proportional to their share in the firm's total employment. For example, a firm with 300 employees (namely, 60 managers, 180 white-collar workers and 60 blue-collar workers) will have to report 
information on 30 workers (namely, 6 managers, 18 white-collar workers and 6 blue-collar workers). For more details see Demunter (2000).

xiii For instance, we eliminate a (very small) number of firms for which the recorded value added was negative.

${ }^{\text {xiv }}$ This restriction is unlikely to affect our results as it leads to a very small drop in sample size. The average number of observations per firm in each year is equal to 37 in our final sample.

${ }^{x v}$ The share of FTC workers is measured as the proportion of hours worked by these workers over the total amount of hours worked within firms.

xvi Our GMM-SYS coefficients on lagged dependent variables fall systematically between the OLS and FE estimates (available on request). As highlighted by Roodman (2009), this outcome supports the appropriateness of our dynamic GMM-SYS specification.

xvii First and second lags of explanatory variables (except time dummies) are used as instruments.

xviii Industry sectors refer to NACE codes C (Mining and quarrying), D (Manufacturing), E (electricity, gas and water supply) and F (construction). Services sectors include NACE codes G (Wholesale and retail trade; repair of motor vehicles, motorcycles and household goods), H (Hotels and restaurants), I (Transport storage and communication), J (Financial intermediation) and $\mathrm{K}$ (Real estate, renting and business activities).

${ }^{\text {xix }}$ No specific regression has been run for NACE code E (electricity, gas and water supply) as it represents less than 1 per cent of firm-year observations in our sample.

${ }^{\mathrm{xx}}$ Full results for detailed industrial sectors are omitted for space reasons but available upon request. 